\title{
Beyond smart tourism cities - towards a new generation of "wise" tourism destinations
}

\author{
J. Andres Coca-Stefaniak
}

\begin{abstract}
Purpose - The purpose of this trends paper is to offer insights into the technological changes affecting our cities and urban tourism destinations, and to explore avenues for further research and practice in the context of smart tourism destinations.

Design/methodology/approach - The literature on smart cities and smart tourism destinations is analysed in view of delivering a research agenda for a new generation of "post-smart" tourism destinations, beyond existing paradigms in this field.

Findings - Smart tourism research to date is found to be lacking in terms of addressing emerging ("postsmart") social issues increasingly faced by global tourism cities, such as growing inequalities between host communities and visitors, wellness (e.g. slow tourism and slow cities) and resilience and mental health (e.g. digital detox), among others.

Practical implications - A post-smart approach to tourism city management and marketing calls for rethinking of existing tourism and urban policies that address wider sustainability issues exemplified by the urban transitions debate as well as adopting a more holistic networked approach to smartness involving entire regions. This also calls for the development of a new research agenda in urban tourism through a new prism - the post-smart "wise" tourism destination.

Originality/value - A new tourism futures construct - the "wise" tourism destination - is posited. This is done within the context of a new ("post-smart") generation of tourism cities. It is argued that "wise" tourism cities will require novel attributes and adopt a visionary strategic positioning well beyond today's smart tourism destination paradigms. Additionally, a tentative research agenda for "wise" tourism cities is discussed.
\end{abstract}

Keywords Smart tourism, Smart cities, Tourism cities, Urban transitions, Wise destinations

Paper type Trends paper

\section{Introduction: the rise of the smart tourism destination}

The pace of technological change affecting the world today is unprecedented, with advances in computing power over the past five decades following largely Moore's Law (Li et al., 2019), which is exponential in nature. Scholars have posited that disruptive technologies (Bower and Christensen, 1995) have been key catalysts in what has been termed as humanity's "fourth industrial revolution" (Schwab, 2017) led by major advances in technology, which arguably affect (nearly) every single aspect of people's daily life (World Economic Forum, 2016). The application of "smart" principles to urban environments is a well-established sphere of knowledge, spanning three decades of research and practice in smart cities (Vanolo, 2014; Cocchia, 2014; Ramaprasad et al., 2017; Lytras and Visvizi, 2018; Ismagilova et al., 2019), focussing on a myriad of urban management aspects, including energy management (Calvino et al., 2016), environmental sustainability (Ahvenniemi et al., 2017), transport infrastructure (Lyons, 2018) or governance (Meijer and Bolivar, 2016), amongst other strategic challenges. In spite of this, topics such as the
J. Andres Coca-Stefaniak is based at the Department of Marketing, Events and Tourism, University of Greenwich, London, UK.
Received 4 November 2019 Revised 28 January 2020 Accepted 28 January 2020

(c) J. Andres Coca-Stefaniak. Published in Journal of Tourism Futures. Published by Emerald Publishing Limited. This article is published under the Creative Commons Attribution (CC BY 4.0) license. Anyone may reproduce, distribute, translate and create derivative works of this article (for both commercial and non-commercial purposes) subject to full attribution to the original publication and authors. The full terms of this license may be seen at http:// creativecommons.org/licences/ by/4.0/legalcode 
marketing and branding of smart cities on their own merits of "smartness" remain in their infancy (Molinillo et al., 2019) and a rich vein for further research (Coca-Stefaniak and Seisdedos, 2020).

Against this backdrop, a parallel concept has started to emerge in tourism - the smart tourism destination (Buhalis, 2000). In a parallel vein to that of smart cities, the concept of smart tourism destinations has evolved over time from an initial focus on technology (Huang et al., 2012; Wang et al., 2013) to the enhancement of tourists' and visitors' experiences (Guo et al., 2014; Zhu et al., 2014; Buhalis and Amaranggana, 2015; Boes et al., 2016; Trunfio and Campana, 2019; Buhalis, 2020). Similarly, special issues on this topic have been published in 2019 in Tourism Review (Koo et al., 2019), the Journal of Hospitality and Tourism Technology (Rasoolimanesh et al., 2019) and, three years earlier, in the International Journal of Tourism Cities (Boes et al., 2016). However, as smart cities research and practice continue to evolve, it is becoming increasingly apparent that smart tourism destination research has a lot more to offer than a mere focus on experience design or even sustainability, including the strategic dilemma of what contribution (if any) smart tourism destinations should make to place marketing -a topic explored further in a special issue on Overtourism and the Marketing of Smart Tourism Destinations recently published in the International Journal of Tourism Cities (Coca-Stefaniak, 2019). This article ponders some of the options ahead in this context and posits the need for a new generation of post-smart tourism destinations with a broader strategic positioning agenda beyond mere "smart" principles - the wise tourism destination.

\section{The next generation of smart tourism destinations}

Although a focus on experience design and delivery is likely to remain at the heart of smart tourism destination research for the foreseeable future, the convergence of smart tourism destination research with that of smart cities (Jasrotia and Gangotia, 2018) is likely to result in a refocussing of tourism research in this field, including a combination of more peoplecentred developments (Lara et al., 2016; Johnson and Samakovlis, 2019) with more radical and contested approaches such as degrowth (March, 2018) to address issues such as overtourism (Dodds and Butler, 2019), local community alienation (Moreno-Gil and CocaStefaniak, 2020) and altogether more sustainable futures for urban tourism destinations (Miller et al., 2015; Wise, 2016; Maxim, 2016; Potsma et al., 2017). In fact, this focus on sustainable futures is being increasingly adopted as a prerequisite of "smartness" with a growing consensus on this front among scholars in urban research (Yigitcanlar et al., 2019) as well as tourism (Vargas-Sanchez et al., 2019). Furthermore, the traditional domination of the "smart" concept by urban environments has been challenged recently by a new paradigm that revolves around rural locations with the emergence of the "smart village" concept (Visvizi and Lytras, 2018; or de Viron and Mudri, 2019), which is also set to become a rich vein for smart tourism research.

\section{Post-smart "wise" tourism cities - towards a research agenda}

Smart cities and smart tourism destinations are not a panacea. In fact, the applicability of smart initiatives to places has been critiqued on a number of fronts (Kitchin, 2015; Sadowski and Bendor, 2019), including arguments positing that the smart city concept bears an uncanny resemblance to earlier constructs (Hollands, 2008), including the entrepreneurial city. The dependence of smart tourism destinations on technology and the growing influence of social media on the brand of urban tourism destinations (Mistilis et al., 2014; Harrigan et al., 2017; Gretzel and Collier de Mendonça, 2019; Gretzel et al., 2019) have also led some scholars to question their vulnerability to new forms of terrorism (Barbe et al., 2018; Coca-Stefaniak and Morrison, 2018), fake news (Cassinger et al., 2018) and online data security (Silva et al., 2018), which can have a considerable negative impact on the 
reputation of tourism destinations in the short- and medium-term. As a result, it is becoming increasingly apparent that the future of smart cities and smart tourism destinations will be intimately linked to their resilience to future challenges [Mboup and Oyelaran-Oyeyinka (2019) and Zhu et al. (2019) for perspectives from Africa and China, respectively], rather than merely their technological prowess. Moreover, the on-going debate of whether cities (and a number of urban destinations that herald themselves as "smart") should reconsider their stance and become "dumb" instead (Boulton et al., 2011; Höjer and Wangel, 2015; Saxe, 2019) is unlikely to fizzle away any time soon. Regardless, and perhaps on a more serious note, issues such as overtourism (Seraphin et al., 2018; Dodds and Butler, 2019; Milano et al., 2019), ageing populations in technologically advanced nations (e.g. Japan, China, Germany, South Korea, Spain and Italy) and the rise of inequality in some of our global (and often "smart") cities (Willis, 2019; Marchetti et al., 2019), among other long-term strategic challenges, are the factors that will need to be addressed by a new generation of, arguably, "wise" cities - a concept first posited within the context of smart cities by Hambleton (2015) and Carrera (2016).

For this "post-smart" generation of tourism destinations, one of the key challenges to be addressed relates to a fundamental change in strategic mindset. In other words, although sustainability will remain a key issue, wise tourism cities will need to look beyond it (Young and Lieberknecht, 2019) through a more comprehensive understanding of developing trends, including the need for tourists and residents alike to switch off from digital media (Jovicic, 2019) and perform regular digital detox routines (Brabazon, 2016; Li et al., 2018) to boost their mental health and resilience (Wiederhold, 2017; Hunt, 2019). In some cases, big data analytics may be part of the solution for these needs (Azevedo Guedes et al., 2018). In other instances, slow tourism initiatives will help to deliver some of these post-smart urban destination thinking, which will become increasingly sophisticated (Tocci, 2017). These topics remain underresearched in tourism, particularly when considering perspectives such as urban transitions (Hodson et al., 2017; Frantzeskaki et al., 2017) and social innovation (Baccarne et al., 2014; Sauer et al., 2016).

A new generation of wise tourism destinations could be the first to address these long-term challenges, often adopting a networked - though still people-centred - approach involving cooperation across a wider regional ecosystem of smart tourism destinations in a manner not dissimilar from existing urban innovation initiatives (Ernstson et al., 2010). In fact, one of the defining characteristics of wise tourism destinations will be in their ability to build on this wider more regional concept of smartness by going beyond the urban sphere and creating symbiotic relationships with nearby "smart villages" (Visvizi and Lytras, 2018), which would close the loop of smart tourism research by linking the urban with the rural using a more integrated regional approach (Gretzel, 2018). This is, again, a topic that very few studies have explored to date (Garau, 2015).

The advent of "wise" post-smart tourism cities will require research into the strategic approaches adopted by destinations culminating in a typology that helps to classify these approaches and define the salient characteristics that delineate a "wise" tourism destination. In this respect, a quantitative indicator-based approach would help to rank these destinations along the "wise" tourism city continuum. Similarly, an assessment of their approaches to delivering long-term visionary processes beyond liveability for residents or merely satisfied visitors may require novel and more interdisciplinary research frameworks. Some of these research prisms, though, already exist and include the study of transformational and inspiring experiences (Robledo and Batle, 2017) or the mechanisms involved in the development of people-centred living laboratories that foster people's creativity and intellectual inquisitiveness (Voytenko et al., 2016). However, one of the biggest challenges for these technology-savvy destinations with an advanced (e.g. big data) understanding of human nature with all its nuances will remain to facilitate processes 
that empower people to achieve purposeful and fulfilling lives and, above all, addressing growing levels of loneliness among different age groups in a hyper-connected world.

In essence, wise tourism destinations will be more people-centred in their use of technology but will also seek to build their resilience by contributing to the wellness of their residents and visitors as well as adopting a wider ranging regional ecosystem approach to sustainable development and innovation. It will be attributes arising from these initiatives that will make wise tourism destinations not only more attractive to visitors as short-term destinations but also inherently more liveable and, therefore, attractive for potential new residents too. Given that these characteristics will be linked closely to the DNA or "personality" (Coca-Stefaniak, 2013) of these city-regions, this will also make their marketing much more competitive as it will be based at least partly on their uniqueness and, crucially, directly related to their smartness, even if this will be a "wiser" and more advanced type of smartness than the techno-centric approaches, which continue to prevail in today's smart city research and practice.

\section{References}

Ahvenniemi, H., Huovila, A., Pinto-Seppä, I. and Airaksinen, M. (2017), "What are the differences between sustainable and smart cities?", Cities, Vol. 60, pp. 234-245.

Azevedo Guedes, A.L., Carvalho Alvarenga, J., Dos Santos Sgarbi Goulart, M., Rodriguez, R., Vicente, M. and Pereira Soares, C.A. (2018), "Smart cities: the main drivers for increasing the intelligence of cities", Sustainability, Vol. 10 No. 9, p. 3121.

Baccarne, B., Mechant, P., Schuurman, D., Colpaert, P. and De Marez, L. (2014), "Urban socio-technical innovations with and by citizens", Interdisciplinary Studies Journal, Vol. 3 No. 4, pp. 143-156.

Barbe, D., Pennington-Gray, L. and Schroeder, A. (2018), "Destinations' response to terrorism on Twitter", International Journal of Tourism Cities, Vol. 4 No. 4, pp. 495-512.

Boes, K., Buhalis, D. and Inversini, A. (2016), "Smart tourism destinations: ecosystems for tourism destination competitiveness", International Journal of Tourism Cities, Vol. 2 No. 2, pp. 108-124.

Boulton, A., Brunn, S.D. and Devriendt, L. (2011), "18 Cyberinfrastructures and 'smart'world cities: physical, human and soft infrastructures", International Handbook of Globalization and World Cities, Edward Elgar Publ, Cheltenham, pp. 198-215.

Bower, J.L. and Christensen, C.M. (1995), "Disruptive technologies: catching the wave", Harvard Business Review, Vol. 1, pp. 27-37.

Brabazon, T. (2016), Digital Dieting: From Information Obesity to Intellectual Fitness, Routledge, London.

Buhalis, D. (2020), "Technology in tourism-from information communication technologies to eTourism and smart tourism towards ambient intelligence tourism: a perspective article", Tourism Review, Vol. 75 No. 1, available at: https://doi.org/10.1108/TR-06-2019-0258

Buhalis, D. (2000), "Marketing the competitive destination of the future", Tourism Management, Vol. 21 No. 1, pp. 97-116.

Buhalis, D. and Amaranggana, A. (2015), "Smart tourism destinations enhancing tourism experience through personalisation of services", in Tussyadiah I. and Inversini A. (Eds), Information and Communication Technologies in Tourism, Springer, New York, pp. 377-389.

Calvino, C.F., Sánchez-Miralles, A. and Villar, J. (2016), "Energy management and planning in smart cities", Renewable and Sustainable Energy Reviews, Vol. 55, pp. 273-287.

Carrera, F. (2016), "Wise cities: 'old' big data and 'slow' real time", Built Environment, Vol. 42 No. 3, pp. 474-497.

Cassinger, C., Eksell, J., Mansson, M. and Thufvesson, O. (2018), "The narrative rhythm of terror: a study of the Stockholm terrorist attack and the 'last night in Sweden' event", International Journal of Tourism Cities, Vol. 4 No. 4, pp. 484-494.

Coca-Stefaniak, J.A. (2013), Successful Town Centres: Developing Effective Strategies, Gloucester First Local Enterprise Partnership, London. 
Coca-Stefaniak, J.A. (2019), "Marketing smart tourism destinations - a strategic dilemma", International Journal of Tourism Cities, Vol. 5 No. 4, pp. 513-518.

Coca-Stefaniak, J.A. and Morrison, A.M. (2018), "City tourism destinations and terrorism-a worrying trend for now, but could it get worse?", International Journal of Tourism Cities, Vol. 4 No. 4, pp. 409-412.

Coca-Stefaniak, J.A. and Seisdedos, G. (2020), "Smart urban tourism destinations at a crossroads when 'smart' and urban are no longer enough", in Morrison A.M. and Coca-Stefaniak J.A. (Eds), Routledge Handbook of Tourism Cities, Routledge, London.

Cocchia, A. (2014), "Smart and digital city: a systematic literature review", in Dameri R.P. and RosenthalSabroux C. (Eds), Smart City - How to Create Public and Economic Value with High Technology in Urban Space, Springer International Publ, New York, NY, pp. 13-43.

de Viron, C.K. and Mudri, G. (2019), "Integrated approach to sustainable EU smart villages policies", Smart Villages in the EU and Beyond, Emerald Publication, Bingley, pp. 13-27.

Dodds, R. and Butler, R. (2019), "The phenomena of overtourism: a review", International Journal of Tourism Cities, Vol. 5 No. 4, pp. 519-528.

Ernstson, H., Van der Leeuw, S.E., Redman, C.L., Meffert, D.J., Davis, G., Alfsen, C. and Elmqvist, T. (2010), "Urban transitions: on urban resilience and human-dominated ecosystems", AMBIO, Vol. 39 No. 8, pp. 531-545.

Frantzeskaki, N., Broto, V.C., Coenen, L. and Loorbach, D. (eds) (2017), Urban Sustainability Transitions, Vol. 5, Taylor \& Francis Publication, London.

Garau, C. (2015), "Perspectives on cultural and sustainable rural tourism in a smart region: the case study of Marmilla in Sardinia (Italy)", Sustainability, Vol. 7 No. 6, pp. 6412-6434.

Gretzel, U. (2018), "From smart destinations to smart tourism regions", Investigaciones Regionales, Vol. 42, pp. 171-184.

Gretzel, U. and Collier de Mendonça, M. (2019), "Smart destination brands: semiotic analysis of visual and verbal signs", International Journal of Tourism Cities, Vol. 5 No. 4, pp. 560-580.

Gretzel, U., Zarezadeh, Z., Li, Y. and Xiang, Z. (2019), "The evolution of travel information search research: a perspective article", Tourism Review, Vol. 75 No. 1, available at: https://doi.org/10.1108/TR-06-2019-0279

Guo, Y., Liu, H. and Chai, Y. (2014), "The embedding convergence of smart cities and tourism internet of things in China: an advance perspective", Advances in Hospitality and Tourism Research, Vol. 2 No. 1, pp. 54-69.

Hambleton, R. (2015), "From smart cities to wise cities", AAG Annual Meeting, Chicago, IL, 21-26 April.

Harrigan, P., Evers, U., Miles, M. and Daly, T. (2017), "Customer engagement with tourism social media brands", Tourism Management, Vol. 59, pp. 597-609.

Hodson, M., Geels, F. and McMeekin, A. (2017), "Reconfiguring urban sustainability transitions, analysing multiplicity”, Sustainability, Vol. 9 No. 2, pp. 1-20.

Höjer, M. and Wangel, J. (2015), "Smart sustainable cities: definition and challenges", ICT Innovations for Sustainability, Springer, Boston, pp. 333-349.

Hollands, R.G. (2008), "Will the real smart city please stand up?", City, Vol. 12 No. 3, pp. 303-320.

Huang, X.K., Yuan, J.Z. and Shi, M.Y. (2012), "Condition and key issues analysis on the smarter tourism construction in China", Multimedia and Signal Processing, Springer Publiction, Berlin: pp. 444-450.

Hunt, E. (2019), "Blue spaces: why time spent near water is the secret to happiness", The Guardian, 3 November, available at: www.theguardian.com/lifeandstyle/2019/nov/03/blue-space-living-near-watergood-secret-of-happiness (accessed 4 November 2019).

Ismagilova, E., Hughes, L., Dwivedi, Y.K. and Raman, K.R. (2019), "Smart cities: advances in research an information systems perspective", International Journal of Information Management, Vol. 47, pp. 88-100.

Jasrotia, A. and Gangotia, A. (2018), "Smart cities to smart tourism destinations: a review paper", Journal of Tourism Intelligence and Smartness, Vol. 1 No. 1, pp. 47-56. 
Johnson, A. and Samakovlis, I. (2019), "A bibliometric analysis of knowledge development in smart tourism research", Journal of Hospitality and Tourism Technology, Vol. 10 No. 4, available at: https://doi. org/10.1108/JHTT-07-2018-0065

Jovicic, D.Z. (2019), "From the traditional understanding of tourism destination to the smart tourism destination", Current Issues in Tourism, Vol. 22 No. 3, pp. 276-282.

Kitchin, R. (2015), "Making sense of smart cities: addressing present shortcomings", Cambridge Journal of Regions, Economy and Society, Vol. 8 No. 1, pp. 131-136.

Koo, C., Mendes Filho, L. and Buhalis, D. (2019), "Smart tourism and competitive advantage for stakeholders", Tourism Review, Vol. 74 No. 1, pp. 1-128.

Lara, A.P., Da Costa, E.M., Furlani, T.Z. and Yigitcanla, T. (2016), "Smartness that matters: towards a comprehensive and human-centred characterisation of smart cities", Journal of Open Innovation: Technology, Market, and Complexity, Vol. 2 No. 1, p. 8.

Li, J., Pearce, P.L. and Low, D. (2018), "Media representation of digital-free tourism: a critical discourse analysis", Tourism Management, Vol. 69, pp. 317-329.

Li, M.Y., Su, S.K., Wong, H.S.P. and Li, L.J. (2019), "How 2D semiconductors could extend Moore's law", Nature, Vol. 567 No. 7747 , pp. 169-170.

Lyons, G. (2018), "Getting smart about urban mobility-aligning the paradigms of smart and sustainable", Transportation Research Part A: Policy and Practice, Vol. 115, pp. 4-14.

Lytras, M. and Visvizi, A. (2018), "Who uses smart city services and what to make of it: toward interdisciplinary smart cities research", Sustainability, Vol. 10 No. 6, pp. 1998.

March, H. (2018), "The smart city and other ICT-led techno-imaginaries: any room for dialogue with degrowth?", Journal of Cleaner Production, Vol. 197, pp. 1694-1703.

Marchetti, D., Oliveira, R. and Figueira, A.R. (2019), "Are global North smart city models capable to assess Latin American cities? A model and indicators for a new context", Cities, Vol. 92, pp. 197-207.

Maxim, C. (2016), "Sustainable tourism implementation in urban areas: a case study of London", Journal of Sustainable Tourism, Vol. 24 No. 7, pp. 971-989.

Mboup, G. and Oyelaran-Oyeyinka, B. (Eds) (2019), Smart Economy in Smart African Cities: sustainable, Inclusive, Resilient and Prosperous, Springer, New York, NY.

Meijer, A. and Bolivar, M.P.R. (2016), "Governing the smart city: a review of the literature on smart urban governance", International Review of Administrative Sciences, Vol. 82 No. 2, pp. 392-408.

Milano, C., Cheer, J.M. and Novelli, M. (Eds) (2019), Overtourism: Excesses, Discontents and Measures in Travel and Tourism, CABI, Wallingford.

Miller, D., Merrilees, B. and Coghlan, A. (2015), "Sustainable urban tourism: understanding and developing visitor pro-environmental behaviours", Journal of Sustainable Tourism, Vol. 23 No. 1 , pp. 26-46

Mistilis, N., Buhalis, D. and Gretzel, U. (2014), "eDestination marketing of the future: the perspective of an Australian tourism stakeholder network”, Journal Travel Research, Vol. 53, pp. 1-13.

Molinillo, S., Anaya-Sánchez, R., Morrison, A.M. and Coca-Stefaniak, J.A. (2019), "Smart city communication via social media: analysing residents' and visitors' engagement", Cities, Vol. 94, pp. 247-255.

Moreno-Gil, S. and Coca-Stefaniak, J.A. (2020), "Overtourism and the sharing economy-tourism cities at a crossroads", International Journal of Tourism Cities, Vol. 6 No. 1.

Potsma, A., Cavagnaro, E. and Spruyt, E. (2017), "Sustainable tourism 2040", Journal of Tourism Futures, Vol. 3 No. 1, pp. 13-22

Ramaprasad, A., Sánchez-Ortiz, A. and Syn, T. (2017), "A unified definition of a smart city", International Conference on Electronic Government, Springer, London, pp. 13-24.

Rasoolimanesh, S.M., Law, R., Buhalis, D. and Cobanoglu, C. (2019), "Progress on information technology in hospitality and tourism", Journal of Hospitality and Tourism Technology, Vol. 10 No. 4, pp. 481-844.

Robledo, M.A. and Batle, J. (2017), "Transformational tourism as a hero's journey", Current Issues in Tourism, Vol. 20 No. 16, pp. 1736-1748. 
Sadowski, J. and Bendor, R. (2019), "Selling smartness: corporate narratives and the smart city as a sociotechnical imaginary”, Science, Technology, \& Human Values, Vol. 44 No. 3, pp. 540-563.

Sauer, T., Elsen, S. and Garzillo, C. (Eds) (2016), Cities in Transition: Social Innovation for Europe's Urban Sustainability, Routledge, London.

Saxe, S. (2019), "I'm an engineer, and I'm not buying into 'smart' cities", The New York Times, 16 July, available at: www.nytimes.com/2019/07/16/opinion/smart-cities.html (accessed 1 November 2019).

Schwab, K. (2017), "The fourth industrial revolution", Currency. [find full reference]

Seraphin, H., Sheeran, P. and Pilato, M. (2018), "Over-tourism and the fall of Venice as a destination", Journal of Destination Marketing \& Management, Vol. 9, pp. 374-376.

Silva, B.N., Khan, M. and Han, K. (2018), "Towards sustainable smart cities: a review of trends, architectures, components, and open challenges in smart cities", Sustainable Cities and Society, Vol. 38, pp. 697-713.

Tocci, G. (2017), "Slow and intelligent cities: when slow is also smart", In: Slow Tourism, Food and Cities, Routledge, London: pp. 126-144.

Trunfio, M. and Campana, S. (2019), "Drivers and emerging innovations in knowledge-based destinations: towards a research agenda", Journal of Destination Marketing \& Management, Vol. 14, pp. 100-370.

Vanolo, A. (2014), "Smartmentality: the smart city as disciplinary strategy", Urban Studies, Vol. 51 No. 5 , pp. 883-898.

Vargas-Sanchez, A., Abbate, T. and Perano, M. (2019), "Smart destinations: towards a more sustainable tourism industry", Management and Sustainability: Creating Shared Value in the Digital Era, SinergieSIMA Conference, Sapienza University, Rome, 20-21 June, pp. 95-112.

Visvizi, A. and Lytras, M.D. (2018), "Rescaling and refocusing smart cities research: from mega cities to smart villages", Journal of Science and Technology Policy Management, Vol. 9 No. 2, pp. 134-145.

Voytenko, Y., McCormick, K., Evans, J. and Schliwa, G. (2016), "Urban living labs for sustainability and low carbon cities in Europe: towards a research agenda", Journal of Cleaner Production, Vol. 123, pp. 45-54.

Wang, D., Li, X. and Li, Y. (2013), "China's 'smart tourism destination' initiative: a taste of the servicedominant logic", Journal of Destination Marketing \& Management, Vol. 2 No. 2, pp. 59-61.

Wiederhold, B.K. (2017), "How digital anxieties are shaping the next generation's mental health", Cyberpsychology, Behavior and Social Networking, Vol. 20 No. 11, p. 661.

Willis, K.S. (2019), "Whose right to the smart city?", The Right to the Smart City, Emerald Publ., Bingley: pp. 27-41

Wise, N. (2016), "Outlining triple bottom line contexts in urban tourism regeneration", Cities, Vol. 53, pp. 30-34

World Economic Forum (2016), "The future of jobs: employment, skills and workforce strategy for the fourth industrial revolution", Global Challenge Insight Report, World Economic Forum, Geneva.

Yigitcanlar, T., Kamruzzaman, M., Foth, M., Sabatini-Marques, J., da Costa, E. and loppolo, G. (2019), "Can cities become smart without being sustainable? A systematic review of the literature", Sustainable Cities and Society, Vol. 45, pp. 348-365.

Young, R.F. and Lieberknecht, K. (2019), "From smart cities to wise cities: ecological wisdom as a basis for sustainable urban development", Journal of Environmental Planning and Management, Vol. 62 No. 10, pp. 1675-1692.

Zhu, S., Li, D. and Feng, H. (2019), "Is smart city resilient? Evidence from China", Sustainable Cities and Society, Vol. 1, pp. 101-636.

Zhu, W., Zhang, L. and Li, N. (2014), "Challenges, function changing of government and enterprises in Chinese smart tourism", in Xiang Z. and Tussyadiah L. (eds.), Information and Communication Technologies in Tourism, Springer Publication, Dublin. 


\begin{abstract}
About the author
Dr J. Andres Coca-Stefaniak is an Associate Professor of Tourism and Events at the University of Greenwich (UK) and advisor to the China-based World Tourism Cities Federation. He is Co-editor-in-chief of the International Journal of Tourism Cities and formerly Head of Research, Thought Leadership and International Partnerships at the Association of Town and City Management. His research interests include urban tourism, place marketing and branding, smart tourism destinations, smart cities, the management and competitiveness of places (including high streets and town centres) and the management of sustainability in events and tourism destinations. Andres has an 18-year track record of securing and managing large EU-funded projects with combined budgets to date in excess of $€ 12 \mathrm{~m}$ and serves on the editorial boards of various journals, including the Journal of Tourism Futures, Journal of Hospitality and Tourism Research Sustainability and the Journal of Place Management and Development, among others. He is Co-editor (with Professor Alastair M Morrison) of the Routledge Handbook of Tourism Cities, due to be published in the Summer/Autumn of 2020. J. Andres Coca-Stefaniak can be contacted at: a.coca-stefaniak@gre.ac.uk
\end{abstract}

For instructions on how to order reprints of this article, please visit our website: www.emeraldgrouppublishing.com/licensing/reprints.htm

Or contact us for further details: permissions@emeraldinsight.com 